\title{
Anti microbial activity of different dosage forms of Bakuchi (Psoralea corylifolia Linn.) taila, An Ayurvedic formulation
}

\author{
Research Article
}

\author{
Acharya $\mathbf{M J}^{1^{*}}$, Singh $\mathrm{TR}^{2}$, Patgiri $\mathbf{B J}^{3}$ \\ 1. M.Pharma Scholar, 2. PhD Research Scholar, 3. Associate Professor \\ Department of Rasashastra and Bhaishajya Kalpana including Drug Research, \\ Institute for Post Graduate Teaching and Research in Ayurveda, \\ Gujarat Ayurved University Jamnagar 361008
}

\begin{abstract}
Psoralea corylifolia Linn. commonly known as "Bakuchi" used in Indian traditional medicine. Ayurveda for the treatment of leucoderma, scabies, leprosy, psoriasis, dermatitis etc. Bakuchi taila is one of the Ayurvedic formulation which is used externally in skin disease. Hence, an attempt has been made to convert Bakuchi taila into its different dosage forms and to evaluate anti microbial activity against gram positive and gram negative bacilli. Bakuchi taila, Bakuchi gel, Bakuchi siktha taila and Bakuchi ointment possess significant anti microbial activity against Bacillus subtilis, Staphylococcus aureus, Escherichia coli and Klebsiella pneumonia. These results confirmed that potential of Bakuchi seeds (Psoralea corylifolia Linn.) in the development of Ayurvedic topical skin formulations.
\end{abstract}

Keywords: Psoralea corylifolia, Bakuchi, Ayurveda, Topical dosage forms, Anti microbial

\section{Introduction:}

The use of plant and its products has a long history to treat various types of disorders in Indian traditional medicine Ayurveda. Medicinal plants have always been a good source to find new remedies for human health problems. Now days, many plants products used to treat various diseases caused by pathogens. Although extremely effective, antibiotics are able to induce resistance in bacteria. For 450 years, bacterial resistance has been the main factor responsible for the increase of morbidity, mortality and health care costs of bacterial infections (1).

Bakuchi is one of the important herbal resources known to the seers of ancient India. It occupied a prominent role in therapeutics. It is referred frequently in Ayurvedic scriptures as a component of formulations for different pathological conditions. The seeds are bitter, anthelmintic, stimulant, diuretic and diaphoretic. Bakuchi is conventionally used in Ayurvedic system of medicine for the treatment of various kinds of human disorders especially for treatment of skin disorders such as psoriasis, leucoderma and leprosy in the form

*Corresponding Author:

\section{Patgiri BJ}

Associate Professor,

Department of Rasashastra and Bhaishajya Kalpana

including Drug Research,

IPGT\&RA, Gujarat Ayurved University,

Jamnagar -361008 .

Mobile No.: 09979878245

E-mail: patgiri124@gmail.com of internal medication(2) as well as external applications (3). Psoralea corylifolia Linn. seeds has been reported to contain several phytoconstituents including coumarins and flavone components such as psoralen, isopsoralen, psoralidin, neobavaisoflavone, bavachin, corylin, bavachalcone (4) and possess antibacterial, anti-inflammatory (5), antifungal (6), antioxidant (7,8), antiflarial (9), estrogenic (10), antitumour (11) and immunemodulatory activity (12). Tila taila also possesses anti-inflammatory, wound healing etc. properties. The combination of these drugs possibly acts synergistically together to pacify the symptoms of a disease. Lepa (13), Pralepa (14) etc. are few dosage forms of external applications explained in classics of Ayurveda. In addition to this, many medicated oils were also mentioned in classics that have been advocated for external use. Bakuchi taila is mentioned in Aryabhishak for the treatment of Kustha roga especially leucoderma in the form of local application (15). Despite the fact that this form is beneficial; it posses certain inconveniencies while handling, packaging and transportation etc. Hence, an attempt has been made to convert Bakuchi taila into Bakuchi siktha taila, Bakuchi ointment and Bakuchi gel for better acceptability and compliance also evaluated anti-microbial activity of Bakuchi taila and its different dosage forms in gram positive and gram negative bacteria.

\section{Materials and Methods \\ Procurement of Raw Material}

Bakuchi seeds (Psoralea corylifolia Linn.), Tila taila (Sesame Oil), Aerosil and Shikta were purchased 
from Ayucare Pharmaceuticals, Ahmedabad and glycerine was procured from laboratory of Rasashastra \& Bhaisajya Kalpana Dept IPGT\&RA, Gujarat Ayurved University, Jamnagar. ATCC 6633 Bacillus subtilis, MTCC 3160 Staphylococcus aureus, MTCC 443 Escherichia coli and MTCC 7162 Klebsiella pneumonia were collected from Ayucare Pharmaceutical Ahmedabad, Gujarat.

\section{Preparation of Bakuchi taila}

The preparation of Bakuchi taila was carried out following the procedure described in the Sarangadhar samhita (16). The taila paka process involves three different media i.e. kalka (paste), taila and drava (kwatha/milk etc.) in the ration 1:4:16 respectively. Bakuchi kwatha was prepared by taking Bakuchi seeds 1 part and 16 part of water was adding into it. They were kept for overnight (12 hours) and next day heating process was carried out in Mandagni i.e. $95-1000 \mathrm{C}$ till the volume reduced to $1 / 4$ th and material was filtered with the help of cotton cloth and Bakuchi kwatha was collected. For Bakuchi kalka, fine powder of Bakuchi was prepared with the help of mortar and pestle. After that, it was triturated with sufficient quantity of water and kalka was prepared. For taila paka process, tila taila (Sesame oil) was taken in a stainless steel vessel and heated in Mandagni till the moisture completely evaporates. Bakuchi kalka was added in it followed by addition of Bakuchi kwatha. Heating was continued maintaining the temperature between $95-1000 \mathrm{C}$ with occasional stirring to avoid sticking of the paste in the bottom of the vessel. Heating was continued till Sneha siddhi lakashana like Varti-vat, Sneha kalka (wick-like shape), Sabdhinoagni nikshipto (does not produce crackling sound on fire) etc was obtained. When Sneha siddhi lakashanas was obtained, Taila was filtered with the help of cotton cloth. This filtered Taila was known as Bakuchi taila.

\section{Preparation of Bakuchi Gel}

Bakuchi taila was taken in a porcelain mortar and small quantity of aerosil was added in it. The contents were homogenized by the action of stirrer. Stirring was done continuously aerosil was added till desired consistency of product was obtained and stored in air tight container.

\section{Preparation of Bakuchi siktha taila}

Bakuchi siktha taila was prepared by modifying the reference of Siktha taila of Rasatarangini (17). In this method, Tila taila was replaced by Bakuchi taila. Siktha and Bakuchi taila were taken in the ration 1:5 respectively. Bakuchi taila was heated in stainless steel vessel till temperature reaches at $800 \mathrm{C}$ and then Siktha was added in it. Continuous stirring was done for homogenous mixing of Siktha. Heating was stopped after uniform mixing and the material were filtered through a cotton cloth. The filtered material is known as Bakuchi siktha taila.

\section{Preparation of Bakuchi Ointment}

Bakuchi ointment was prepared by following the general reference of ointment preparation in which two phases i.e. oil and water phases were mixed together. Firstly for oil phase, Bakuchi taila and Siktha were heated in a stainless steel vessel with continuous stirring till the contents are uniformly mixed. Simultaneously, the contents of water phase i.e. RO water and Glycerin were also heated in another vessel till uniform mixing was obtained. Then, both the phases were filtered and shifted in a clean mortar followed by continuous stirring to obtain uniform ointment. The finished product obtained was known as Bakuchi ointment.

\section{Anti-microbial activity}

Anti-microbial activity was studied by Agar well diffusion assay (18) method against two gram positive Bacillus subtilis ATCC 6633 \& Staphylococcus aureus MTCC 3160 and two gram negative bacteria Escherichia coli MTCC 443 \& Klebsiella pneumoniae MTCC 7162. Mueller-Hinton agar (Mh agar) was used as media. All the samples were dissolved in hexane (control). $5 \mathrm{~mm}$ well were prepared using sterile cup borer. $20 \mu \mathrm{l}$ of diluted sample were added in the well and incubated at $37^{\circ} \mathrm{c}$ for 24 hours. Results were observed at zone of inhibition, measured in $\mathrm{mm}$. Ampicillin (antibiotic) was used as standard drug and its sensitivity was $11 \mathrm{~mm}$. Bakuchi and its different forms are compared with sensitivity of Ampicillin. If the drug posses $11.5 \mathrm{~mm}$ or more means it is highly sensitive, if it around $8 \mathrm{~mm}$ then it is intermediate and if less than $8 \mathrm{~mm}$ i.e. low sensitive. If the drug doesn't respond then, it is resistant.

\section{Results}

For Bakuchi taila, $100 \mathrm{~g}$ of Bakuchi seeds Kalka (Paste) were mixed in $400 \mathrm{ml}$ of Tila taila followed by addition of $1600 \mathrm{ml}$ of Bakuchi seeds Kwatha (Decoction). Total duration of heating process required for preparation of Bakuchi taila was $18 \mathrm{hrs}$. Total quantity $388 \mathrm{ml}$ of Bakuchi taila was obtained. In Bakuchi gel preparation, $3 \mathrm{~g}$ of aerosil is sufficient to make Bakuchi gel from $50 \mathrm{ml}$ Bakuchi taila. Final gel obtained was $46.4 \mathrm{~g}$ in weight. During preparation of Bakuchi siktha taila it was observed that Siktha was easily mixed in mild hot Bakuchi taila, but continuous stirring was done and final weight was $46.9 \mathrm{~g}$. For Bakuchi ointment $30 \mathrm{ml}$ of Bakuchi taila was mixed in 6 $\mathrm{g}$ of Siktha for oil phase and in water phase $4 \mathrm{~g}$ glycerine and $15 \mathrm{ml}$ of RO water is added in previously prepared Bakuchi siktha taila. Final weight of Bakuchi ointment was $45.3 \mathrm{~g}$. The results obtained during preparation of Bakuchi taila and its different dosage forms are in table 1-2. 


\section{International Journal of Ayurvedic Medicine, 2015, 6(3), 232-236}

\section{Anti-microbial activity}

Bakuchi ointment shows greater inhibitory activity against Gram + ve Bacillus subtilis and Gram ve E. coli whereas Bakuchi taila shows greater inhibitory activity against both Gram +ve Bacillus subtilis and $\mathrm{S}$. aureus. Bakuchi gel shows greater inhibitory activity against Gram +ve S. aureus and Gram -ve Klebsiella pneumonia. Bakuchi siktha taila shows greater inhibitory activity against Gram -ve
Klebsiella pneumonia. All the dosage forms of Bakuchi show remarkable inhibitory against Gram +ve and Gram -ve. Although, inhibition was more against Gram +ve bacteria, the highest zone of inhibition was of Bakuchi gel $15 \mathrm{~mm}$ at only $20 \mu \mathrm{l}$ drug concentration against S. aureus (Gram +ve) which is highly sensitive, then the standard drug Ampicillin which has $11.5 \mathrm{~mm}$ inhibition (Table 3-4).

Table 1: Results obtained during preparation of Bakuchi taila and its different dosage forms

\begin{tabular}{|l|l|l|l|l|l|l|l|l|l|l|}
\hline $\begin{array}{l}\text { Dosage } \\
\text { forms }\end{array}$ & $\begin{array}{l}\text { Initial } \\
\text { quantity } \\
\text { of } \\
\text { Bakuchi } \\
\text { kalka }\end{array}$ & $\begin{array}{l}\text { Initial } \\
\text { quantity } \\
\text { of Tila } \\
\text { taila }\end{array}$ & $\begin{array}{l}\text { Initial } \\
\text { quantity } \\
\text { of } \\
\text { Bakuchi } \\
\text { kwatha }\end{array}$ & $\begin{array}{l}\text { Initial } \\
\text { quantity } \\
\text { of } \\
\text { Bakuchi } \\
\text { taila }\end{array}$ & $\begin{array}{l}\text { Initial } \\
\text { quantity } \\
\text { of } \\
\text { aerosil }\end{array}$ & Siktha & $\begin{array}{l}\text { Glyceri } \\
\text { ne }\end{array}$ & $\begin{array}{l}\text { RO } \\
\text { water }\end{array}$ & $\begin{array}{l}\text { Final } \\
\text { quantity }\end{array}$ & Loss \\
\hline $\begin{array}{l}\text { Bakuchi } \\
\text { taila }\end{array}$ & $100 \mathrm{~g}$ & $400 \mathrm{ml}$ & $1600 \mathrm{ml}$ & - & & - & - & & $388 \mathrm{ml}$ & $12 \mathrm{ml}$ \\
\hline $\begin{array}{l}\text { Bakuchi } \\
\text { Gel }\end{array}$ & - & - & - & $50 \mathrm{ml}$ & $3 \mathrm{~g}$ & - & - & - & $50.4 \mathrm{~g}$ & $2.6 \mathrm{~g}$ \\
\hline $\begin{array}{l}\text { Bakuchi } \\
\text { siktha } \\
\text { taila }\end{array}$ & - & - & - & $50 \mathrm{ml}$ & - & $10 \mathrm{~g}$ & - & - & $55.9 \mathrm{~g}$ & $4.1 \mathrm{~g}$ \\
\hline $\begin{array}{l}\text { Bakuchi } \\
\text { Ointment }\end{array}$ & - & - & - & $30 \mathrm{ml}$ & - & $6 \mathrm{~g}$ & $4 \mathrm{~g}$ & $15 \mathrm{ml}$ & $50 \mathrm{~g}$ & $4 \mathrm{~g}$ \\
\hline
\end{tabular}

Table 2: Organoleptic characteristics of Bakuchi taila and its dosage forms

\begin{tabular}{|l|l|l|l|l|}
\hline Parameters & Bakuchi taila & Bakuchi siktha taila & Bakuchi Ointment & Bakuchi Gel \\
\hline Color & Yellowish brown & Yellowish Cream & Cream & Golden \\
\hline Odour & Characteristic & Characteristic & Characteristic & Characteristic \\
\hline Touch & Oily & Greasy & Greasy & Greasy \\
\hline Consistency & $\begin{array}{l}\text { Smooth, } \\
\text { Non gritty }\end{array}$ & $\begin{array}{l}\text { Smooth, } \\
\text { homogenous }\end{array}$ & $\begin{array}{l}\text { Smooth, semi solid, } \\
\text { homogenous }\end{array}$ & $\begin{array}{l}\text { Smooth, } \\
\text { homogenous }\end{array}$ \\
\hline Texture & -- & $\begin{array}{l}\text { Smooth, Creamy, Non } \\
\text { gritty }\end{array}$ & Smooth, Non gritty & $\begin{array}{l}\text { Smooth, Jranslucent, Non } \\
\text { gritty }\end{array}$ \\
\hline
\end{tabular}

Table no. 3: Results of Zone of Inhibition in Gram positive bacteria

\begin{tabular}{|l|l|l|l|l|}
\hline Strain & Sample & Conc. of Drug & $\begin{array}{l}\text { Zone } \\
\text { Inhibition }\end{array}$ & $\begin{array}{l}\text { Sensitivity Against } \\
\text { Ampicillin }\end{array}$ \\
\hline \multirow{4}{*}{$\begin{array}{l}\text { Bacillus subtilis } \\
\text { ATCC 6633 }\end{array}$} & Bakuchi taila & $20 \mu \mathrm{l}$ & $10 \mathrm{~mm}$ & $\mathrm{~S}$ \\
\cline { 2 - 5 } & Bakuchi siktha taila & $20 \mu \mathrm{l}$ & $9 \mathrm{~mm}$ & $\mathrm{~S}$ \\
\cline { 2 - 5 } & Bakuchi Gel & $20 \mu \mathrm{l}$ & $\mathrm{Nil}$ & $\mathrm{R}$ \\
\cline { 2 - 5 } & Bakuchi Ointment & $20 \mu \mathrm{l}$ & $11 \mathrm{~mm}$ & $\mathrm{~S}$ \\
\hline \multirow{3}{*}{$\begin{array}{l}\text { Staphylococcus } \\
\text { aureus } \\
\text { MTCC 3160 }\end{array}$} & Bakuchi taila & $20 \mu \mathrm{l}$ & $13 \mathrm{~mm}$ & $\mathrm{HS}$ \\
\cline { 2 - 5 } & Bakuchi siktha taila & $20 \mu \mathrm{l}$ & $11 \mathrm{~mm}$ & $\mathrm{~S}$ \\
\cline { 2 - 5 } & Bakuchi Gel & $20 \mu \mathrm{l}$ & $15 \mathrm{~mm}$ & $\mathrm{HS}$ \\
\cline { 2 - 5 } & Bakuchi Ointment & $20 \mu \mathrm{l}$ & $12 \mathrm{~mm}$ & $\mathrm{HS}$ \\
\hline
\end{tabular}

S, Sensitive; R, Resistant; I, Intermediate; HS, Highly sensitive. 
Patgiri B J et.al., Antimicrobial activity of the different dosage forms of Bakuchi taila

Table no. 4: Results of Zone of Inhibition in Gram negative bacteria

\begin{tabular}{|l|l|l|l|l|}
\hline Strain & Sample & $\begin{array}{l}\text { Conc. of } \\
\text { Drug }\end{array}$ & $\begin{array}{l}\text { Zone } \\
\text { Inhibition }\end{array}$ & $\begin{array}{l}\text { Sensitivity } \\
\text { Ampicillin }\end{array}$ \\
\hline \multirow{4}{*}{$\begin{array}{l}\text { Escherichia } \\
\text { coli }\end{array}$} \\
MTCC 443 & Bakuchi taila & $20 \mu \mathrm{l}$ & $7 \mathrm{~mm}$ & LS \\
\cline { 2 - 6 } & Bakuchi siktha taila & $20 \mu \mathrm{l}$ & $7 \mathrm{~mm}$ & LS \\
\cline { 2 - 6 } & Bakuchi Gel & $20 \mu \mathrm{l}$ & $7 \mathrm{~mm}$ & LS \\
\cline { 2 - 6 } & Bakuchi Ointment & $20 \mu \mathrm{l}$ & $8 \mathrm{~mm}$ & $\mathrm{I}$ \\
\hline \multirow{3}{*}{$\begin{array}{l}\text { Klebsiella } \\
\text { pneumoniae } \\
\text { MTCC 7162 }\end{array}$} & Bakuchi taila & $20 \mu \mathrm{l}$ & $8 \mathrm{~mm}$ & $\mathrm{I}$ \\
\cline { 2 - 6 } & Bakuchi siktha taila & $20 \mu \mathrm{l}$ & $10 \mathrm{~mm}$ & $\mathrm{~S}$ \\
\cline { 2 - 6 } & Bakuchi Gel & $20 \mu \mathrm{l}$ & $9 \mathrm{~mm}$ & $\mathrm{~S}$ \\
\cline { 2 - 6 } & Bakuchi Ointment & $20 \mu \mathrm{l}$ & $8 \mathrm{~mm}$ & $\mathrm{I}$ \\
\hline
\end{tabular}

LS, Low sensitive; I, Intermediate; S, Sensitive.

\section{Discussion}

Ayurveda, the science of life uses natural resources in fulfilling the fundamental objectives i.e. Swasthya rakshanam and Vyadhi prashamanam. Plants occupy a significant seat of these resources. The use of plants and its products are useful to treat several ailments from 5000 years ago. Bakuchi (Psoralea corylifolia Linn.) is one of the most popular Indian Traditional Medicine and officially listed in Ayurvedic Pharmacopoeia of India (19). As per classical literature, Bakuchi is useful to treat various disorders like Kushtha (skin disorders), Keshya (hair treatments), Krumi (as a germicidal), Shwasa (Bronchial Asthma), Kasa (Cough), Pandu (Anemia), and Shotha (Oedema) (20). In our present study, Bakuchi taila was prepared by following the standard method of Sneha paka which is described in Sarangdhar samhita (21). Further, it was converted into different dosage forms like Bakuchi siktha taila, Bakuchi gel \& Bakuchi ointment. In preparation of Bakuchi taila our results demonstrate that minimum $18 \mathrm{hrs}$ of heating is necessary to get desired quality of Bakuchi taila. Kalka dravya used for preparation was made in to fine powder so that maximum percentage of active constituents goes in to preparation. The weight of $\mathrm{Kalka}$ dravya after preparation was increased and found 110 gm. This increase the amount of Kalka dravya due to absorption of Taila and Dravya dravya used in preparation. Final weight of Bakuchi taila was decreased than that of Tila taila because of absorption of Kalka dravya. Preparation of Bakuchi taila was done in Madhyam agni at temperature between $95-100^{\circ} \mathrm{C}$ because at higher temperature Kalka dravya gets burned and all liquid material will evaporate quickly and no Drava dravya would be available for preparation. In case of Bakuchi gel for $50 \mathrm{ml}$ of Bakuchi taila, $3 \mathrm{gm}$ of aerosol is sufficient to make gel. Bakuchi siktha taila was prepared by modifying the reference of Siktha taila of Rasa tarangini. Bakuchi ointment was prepared by following the protocol of mixing of oil and water phase homogenously and continuous stirring was done.

In the present study, different dosage forms of Bakuchi i.e. Bakuchi taila, Bakuchi gel, Bakuchi siktha taila and Bakuchi ointment were evaluated for their anti microbial activity. The bacilli are grossly divided as gram positive and gram negative bacteria. So, as to test the anti microbial activity, a gram positive and gram negative bacteria bacilli are selected for the study. Staphylococcus aureus, Bacillus subtilis (gram positive) and Escherichia coli, Klebsiella pneumonia (gram negative) which are the most common causes of diseases in human beings were selected for the study. Our results demonstrates that all the dosage forms of Bakuchi shows good inhibitory activity against both gram positive and gram negative bacteria. However, inhibitory activity against gram positive bacteria was comparatively more than gram negative. Out of all dosage forms, Bakuchi gel was giving highest zone of inhibition against Staphylococcus aureus a gram positive bacterium. Bakuchi contain active component as psoralen, angelicin, and bakuchiol $(22,23)$. Psoralen shows strong inhibition of bacteria, such as Microsporium canis, Microsporium gypseum, Trichophyton rubrum, Trichophyton mentagrophytes, $S$. aureus, Candida albicans, Escherichia coli, P. aeruginosa, and others (24). Chopra et al. also reported that anti microbial activity of Bakuchi was due to the presence of bakuchiol (25).

\section{Conclusion}

This study revealed that Bakuchi taila and its different dosage forms possess significant Anti microbial activity against gram positive and gram negative bacteria. So, it can be used as bioactive anti microbial ingredients in various topical skin formulations. 


\section{References}

1. Biradar YS, Jagtaap S, Khandelwal KR, Singhania SS. Exploring of Antimicrobial Activity of Triphala Mashi-an Ayurvedic Formulation. eCAM 2008;5 (1)107-113.

2. Siddhinandan Mishra., Bhaishajya Ratnavali Chaukhambha Publication Varanasi, Edition 2009 (54/353-358), Khadirarishta-Kushtharogadhikar.

3. Siddhinandan Mishra., Bhaishajya Ratnavali Chaukhambha Publication Varanasi, Edition 2009 (54/302-310), Somraji Taila.

4. Y. Wang, C. Hong, C. Zhou, D. Xu and H. B. Qu "Screening antitumour compounds psoralen and isopsoralen from Psoralea corylifolia L. seeds." Evidence-based Complementary and Alternative Medicine, vol. 2011, Article ID363052

5. Bina Gidwaniet al, Anti-inflammatory and antimicrobial activity of hexane extract of seed of Psoralea corylifolia Linn, International Journal of Pharma Research and Development- Online 2010, 10(2), 129-137

6. Prasad NR, Anand C, Balasubramanian S, Pugalendi KV. Antidermatophytic activity of extracts from Psoralea corylifolia (Fabaceae) correlated with the presence of a flavonoid compound. Journal of Ethnopharmacology2004; 91: 21-24.

7. Tang SY, Whiteman M, Peng ZF, Jenner A, Yong EL, Halliwell B. Characterization of Antioxidant and Antiglycation properties and isolation of active ingredients from traditional chinese medicines. Free Radical Biology \& Medicine 2004; 36(12): 15751587.

8. Haraguchi $\mathrm{H}$, Inoue $\mathrm{J}$, Tamura $\mathrm{Y}$, Mizutani $\mathrm{K}$. Inhibition of mitochondrial lipid peroxidation by Bakuchiol, a meroterpene from Psoralea corylifolia. Planta Medica 2000; 66(6): 569-71.

9. Qamaruddin A, Parveen N, Khan NU, Singhal KC. Potential antifilarial activity of the leaves and seeds extracts of Psoralea corylifolia on cattle filarial parasite Setariacervi. Journal of Ethnopharmacology 2003; 84(2-3): 313

10. Zhang CZ, Wang SX, Zhang Y, Chen JP, Liang XM. In vitro estrogenic activities of Chinese medicinal plants traditionally used for the management of menopausal symptoms. Journal of Ethnopharmacology 2005; 98: 295-300.

11. Latha PG, Evans DA, Panikkar KR, Jayavardhanan KK. Immunomodulatory and anti-tumour properties of Psoralea corylifolia seeds. Fitoterapia2000; 71: 223-231.

12. Latha PG, Panikkar KR. Inhibition of chemical carcinogenesis by Psoralea corylifolia seeds. Journal of Ethnopharmacology 1999; 68: 295-298.
13. Pandit Sarangadharacharya son of Pandit Damodar, The Sarangadhar Samhita, with the commentary Adhamalla's Dipika and Kasirama's GudharthaDipika, edited by Pandit Parsurama Sastri, Vidyasagar, Uttara Khanda, chapter 11/2, Varanasi: Chaukhambha orientalia; 2012. p. 355.

14. Pandit Sarangadharacharya son of Pandit Damodar, The Sarangadhar Samhita, with the commentary Adhamalla's Dipika and Kasirama's GudharthaDipika, edited by Pandit Parsurama Sastri, Vidyasagar, Uttara Khanda, chapter 11/71, Varanasi: Chaukhambha orientalia; 2012. p. 362.

15. Sadgad Ayurveda Shastri Shankar Dajipade, Aryabhishak, Translator Vyas Harikrishna Bhagwanlal, Publication Ananad N. Amin sastu sahitay mudranalaya Trust Bhadra Ahmedabad; 2012. p. 313.

16. Sharangadhara Samhita, 'Dipika' Hindi commentary, commented by Brahamanand Tripathi, Madhyam Khanda 9/1, Choukhamba Surbharti Prakashana, Varanasi, 2006, P. 212.

17. Rasatarangini, Sadanand Sharmas, commentary by Pandit Kshinath Shastri Delhi: Motilal Banarasidas Publication, 1979, 4/62-63, p.115.

18. Perez, C., Pauli, M. and Bazerque, P. (1990). An antibiotic assay by agar-well diffusion method. Acta Biologiae et Medecine Experimentaalis, 15:113-115.

19. Anonymous, Ayurvedic Pharmacopoeia of India, Department of Ayush, Ministry of $\mathrm{H}$ and FW, $2^{\text {nd }}$ ed, Part 1 Volume 1. India: Government of India; 2007, p- 43-4.

20. Shri Mishra B.; Bhavpraksh Nighantu with commentary of vidyotini, Chaukhambha Sanskrit sansthan Varanasi, 11th edition - Haritkyadi varga; 2004.

21. Sharangadhara Samhita, 'Dipika' Hindi commentary, commented by Brahamanand Tripathi, Madhyam Khanda 9/1, Choukhamba Surbharti Prakashana, Varanasi, 2006, P. 212.

22. Khastgir HN, Duttagupta PC, Sengupta P. Psoralen and Isopsoralen from Psoralea corylifolia. Indian J Appl Chem. 1959;22:82-5

23. Gupta AK, Neeraj T, Madhu S. Vol. 3. New Delhi: ICMR; 2005. Quality Standards of Indian Medicinal Plants; pp. 290-8.

24. Khushboo PS, Jadhav VM, Kadam VJ, Sathe NS. Psoralea corylifolia Linn.- "Kushtanashini". Pharmacogn Rev. 2010 Jan-Jun; 4(7): 69-76.

25. Chopra B, Dhingra A. Antimicrobial Activity of Psoralea corylifolia Linn. (Baguchi) Seeds Extracts by Organic Solvents and Supercritical Fluids. International research journal of chemistry and Environment 2014; 1(1): 59-64. 